\title{
Evaluation of calf milk pasteurization systems on 6 Pennsylvania dairy farms
}

\author{
J. A. Elizondo-Salazar, ${ }^{1}$ C. M. Jones, and A. J. Heinrichs ${ }^{2}$ \\ Department of Dairy and Animal Science, The Pennsylvania State University, University Park 16802
}

\begin{abstract}
Waste milk has been fed to calves for many years, but concerns with bacterial contamination as well as possible transmission of diseases have discouraged widespread use of this feed. Pasteurization of waste milk is one option to reduce management risk while utilizing a valuable, low-cost, liquid feed source for calves. However, many farms currently pasteurizing waste milk lack a system to adequately monitor the efficiency of the process. A study was carried out to evaluate 6 on-farm pasteurization systems, including high-temperature, short-time pasteurizers and low-temperature, batch pasteurizers. Milk samples were taken pre- and postpasteurization as well as from the calf buckets and immediately frozen for later bacterial culture. Samples were collected twice daily for $15 \mathrm{~d}$. Milk samples were examined for standard plate count (SPC), coagulase-negative staphylococci count, environmental streptococci count, coliform count, gram-negative noncoliform count, Streptococcus agalactiae count, and Staphylococcus aureus count. Before pasteurization, $68 \%$ of the samples had SPC $<20,000 \mathrm{cfu} / \mathrm{mL}$, and $39 \%$ of samples contained $<100$ $\mathrm{cfu} / \mathrm{mL}$ of coliform bacteria. After pasteurization, $96 \%$ of samples had SPC $<20,000 \mathrm{cfu} / \mathrm{mL}$, and $92 \%$ had coliform counts $<100 \mathrm{cfu} / \mathrm{mL}$. Bacteria counts were significantly reduced by pasteurization, and pasteurized milk contained acceptable numbers of bacteria in $>90 \%$ of samples. These results indicate that pasteurization can be very effective in lowering bacterial contamination of milk. However, bacteria numbers significantly increased after pasteurization and, in some cases, bacteria counts in milk fed to calves were similar to prepasteurization levels. Milk handling after pasteurization was identified as an important issue on the farms studied.
\end{abstract}

Key words: pasteurization, waste milk, bacteria

Received May 21, 2010.

Accepted July 22, 2010.

${ }^{1}$ Current address: Estación Experimental Alfredo Volio Mata, Facultad de Ciencias Agroalimentarias, Universidad de Costa Rica, San José, Costa Rica.

${ }^{2}$ Corresponding author: ajh@psu.edu

\section{INTRODUCTION}

Pasteurization of nonsaleable milk has been recommended as a strategy to reduce bacterial contamination and limit spread of diseases that can be transmitted through milk. Research has demonstrated that on-farm batch and high-temperature, short-time pasteurization methods can effectively reduce the number of bacteria in milk (Stabel, 2001; Stabel et al., 2004). However, surveys of milk samples from farms pasteurizing milk for calves have shown considerable variation in the success of these systems (Jorgensen et al., 2006; Ruzante et al., 2008). Jorgensen et al. (2006) sampled milk before and after pasteurization from 31 dairy farms or custom calf-rearing operations. Bacterial loads measured by SPC ranged from 6,000 to $>72$ million $\mathrm{cfu} / \mathrm{mL}$ in raw milk samples. Pasteurization reduced populations of all bacterial species measured; however, the presence of alkaline phosphatase in 4 samples indicated that pasteurization time or temperature was inadequate in some cases.

Further evidence that pasteurization carried out on farms is highly variable was presented by Ruzante et al. (2008), who reported mean log reductions ranging from 2.6 to 4.7 for 4 California calf ranches pasteurizing milk for calves. Samples were collected during each season, and $\log$ reduction during winter was smaller than in other seasons. However, this observation may be due to lower initial bacteria counts in winter months. These studies focused on SPC as the sole criterion for milk quality definitions and used limited types of pasteurizers. The objective of the current experiment was to evaluate performance of differing types of on-farm pasteurization systems from before pasteurization through calf feeding on Pennsylvania farms and to examine the milk for a variety of bacteria.

\section{MATERIALS AND METHODS}

Six farms in central Pennsylvania were selected as a convenience sample for use in this study during the late spring. Farms ranged in size from 500 to 2,000 cows and had each been feeding pasteurized waste milk for more than a year. Two farms employed the HTST or continuous-flow method of pasteurization, where milk is 
heated to $71.6^{\circ} \mathrm{C}$ for $15 \mathrm{~s}$. Two other farms employed the low-temperature, long-time (LTLT) or batch method of pasteurization, in which milk is heated to $62.7^{\circ} \mathrm{C}$ for 30 min. The final 2 farms employed a modification of the LTLT method of pasteurization in which commercial heating coils were purchased and the batch container was homemade. No farm had a routine quality control protocol for monitoring pasteurizer efficacy.

Milk samples were taken pre- and postpasteurization as well as from 1 bucket randomly selected from the calves being fed during that particular feeding, before the calf had access to the bucket. Samples were collected twice daily for $15 \mathrm{~d}$, placed on ice immediately after collection, and then frozen on the farm. At the conclusion of the sampling period, all samples were collected from the farm, transported on ice to the laboratory, and stored at $-20^{\circ} \mathrm{C}$ for later bacterial culture. Every attempt was made to keep samples frozen from collection to analysis. All milk samples were examined for $\mathrm{SPC}$ to enumerate total aerobic bacteria, CNS count, environmental streptococci (ES) count, coliform (CC) count, gram-negative noncoliform (NC) count, Streptococcus agalactiae (SAG) count, and Staphylococcus aureus (SA) count (Jayarao et al., 2004).

Samples were thoroughly mixed by inverting tubes 20 to 25 times, and then $50-\mu \mathrm{L}$ aliquots of each sample were placed on selective and nonselective media using an inoculating loop. Plate count agar was used for enumeration of SPC. The ES and SAG in milk samples were estimated using modified Edward's agar supplemented with colistin sulfate and oxolinic acid (Sawant et al., 2002). MacConkey's agar no. 3 (Oxoid, Basingstoke, UK) was used to determine CC and NC. Baird Parker's agar (Becton Dickinson, Cockeysville, MD) was used to determine CNS and SA. Plates for enumeration of SPC were incubated at $32^{\circ} \mathrm{C}$ for $48 \mathrm{~h}$. Plates for enumeration of CNS, ES, SA, CC, SAG, and NC were incubated at $37^{\circ} \mathrm{C}$ for $48 \mathrm{~h}$. Because all of the farms used milk from treated cows (dry treatment or mastitis treatment) as part of the milk used for calves, this could have caused a small reduction in bacteria levels in milk prepasteurization; however, this aspect of the study could not be controlled and would likely have little effect because most of the milk fed to calves was from fresh cows.

\section{Statistical Analysis}

Descriptive statistics were generated using the UNIVARIATE procedure of SAS (version 9.1.3, SAS Institute Inc., Cary, NC). Bacterial count data were not normally distributed; therefore, logarithmic transformation $\left[\log _{10}(\mathrm{x}+1)\right]$ was applied to approximate normal distribution. Bacteria counts were evaluated using the MIXED procedure of SAS with farm included as a random effect and fixed effects of sample period, pasteurizer type, day, and time. Log reduction of bacteria counts as a result of pasteurization was calculated by $\log _{10}(\mathrm{cfu} / \mathrm{mL}$ before pasteurization $)-\log _{10}(\mathrm{cfu} / \mathrm{mL}$ after pasteurization). Percentage log reduction was calculated by $100 \times\left[\log _{10}(\mathrm{cfu} / \mathrm{mL}\right.$ before pasteurization $)-\log _{10}(\mathrm{cfu} / \mathrm{mL}$ after pasteurization $\left.)\right] / \log _{10}(\mathrm{cfu} /$ $\mathrm{mL}$ before pasteurization); percentage log reduction could not be determined for samples with a zero count before pasteurization. Correlations between all bacteria counts and all sampling periods were evaluated using the CORR procedure of SAS.

\section{RESULTS AND DISCUSSION}

\section{Bacteria Counts Before Pasteurization}

Staphylococcus aureus and Streptococcus agalactiae were not detected in any samples during this study. Table 1 presents descriptive statistics for SPC, ES, CNS, CC, and NC. Each count had a broad range, and the median was much lower than the mean for most counts. Table 2 shows the distribution of bacteria counts in milk samples. Targets for bacteria counts in milk fed to calves are not well established, but McGuirk (2003) proposed the following targets: SPC $<10,000$ $\mathrm{cfu} / \mathrm{mL}$; ES, CNS, and $\mathrm{NC}<5,000 \mathrm{cfu} / \mathrm{mL}$; and CC $0 \mathrm{cfu} / \mathrm{mL}$. Godden et al. (2005) suggested a goal for $\mathrm{SPC}$ of $<20,000 \mathrm{cfu} / \mathrm{mL}$ in milk fed to calves, which is the standard for pasteurized milk for human consumption (Food and Drug Administration, 2003). The US Pasteurized Milk Ordinance also specifies that pasteurized milk for human consumption contain $<10 \mathrm{cfu} / \mathrm{mL}$ of coliform bacteria (Food and Drug Administration, 2003). The FDA does not specify a limit for coliforms in raw milk, but milk quality guidelines suggest a goal of $<100 \mathrm{cfu} / \mathrm{mL}$. Before pasteurization, $68 \%$ of samples in this study had SPC $<20,000 \mathrm{cfu} / \mathrm{mL}$ and $58 \%$ had $<10,000 \mathrm{cfu} / \mathrm{mL}$. Using the McGuirk (2003) targets, 86,93 , and $88 \%$ of samples taken before pasteurization contained $<5,000 \mathrm{cfu} / \mathrm{mL}$ of ES, CNS, and NC. Only $8 \%$ of samples contained $<10 \mathrm{cfu} / \mathrm{mL}$ and just $39 \%$ of samples contained $<100 \mathrm{cfu} / \mathrm{mL}$ of coliform bacteria.

The goal numbers discussed here represent poor quality for saleable raw milk, but nonsaleable milk can be expected to have higher bacteria counts than saleable milk. Few published studies document the exposure level that calves can withstand, and the minimum infective dose is greatly influenced by the general health and nutritional status of individual calves, as well as the organism involved and the presence of concomitant infections. However, increasing exposure increases the risk of disease, and attempts to monitor and limit bacterial contamination of milk fed to calves are prudent. 
Table 1. Bacteria counts (cfu/mL) in milk before and after pasteurization and before being fed to calves (bucket) on 6 Pennsylvania dairy farms

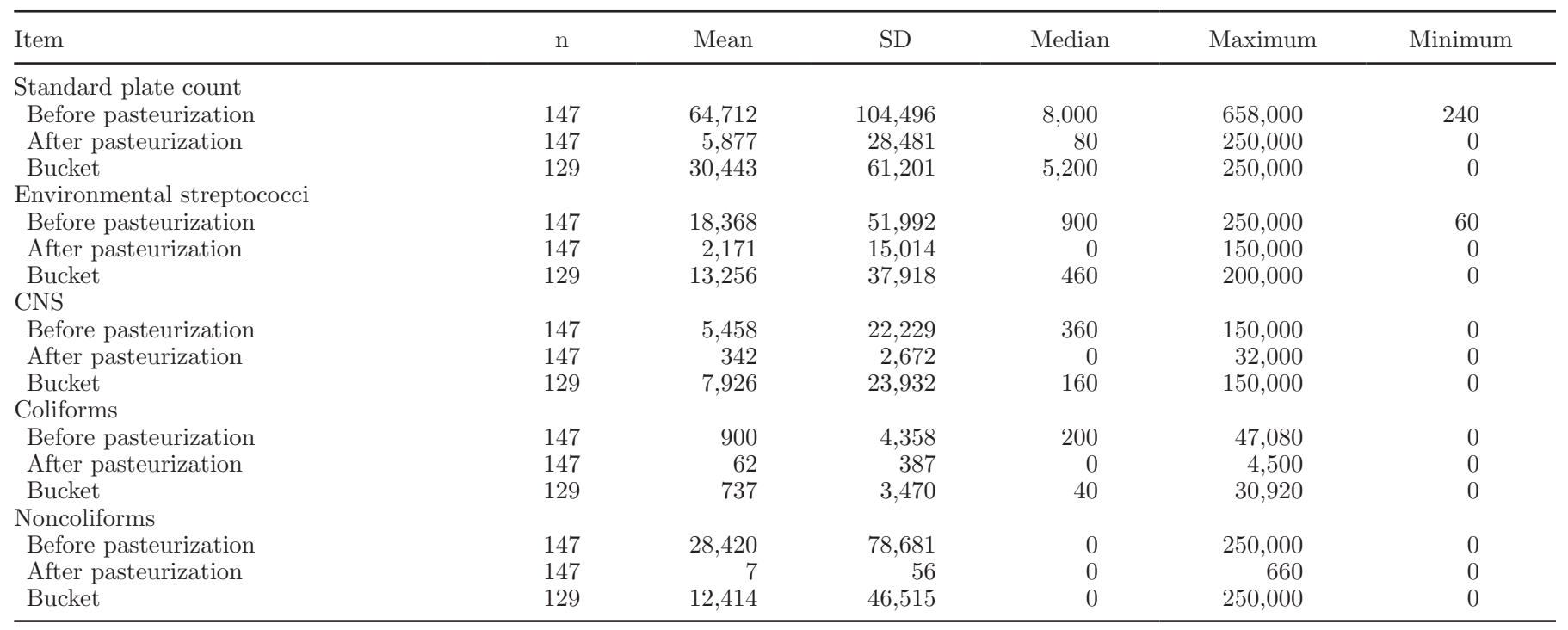

Sources of bacteria in milk fed to calves can include shedding from cows with mastitis, inadequate cleaning of cows before milking, and contamination from poorly cleaned or worn milking equipment. In addition, failure to cool milk rapidly after collection can allow bacteria to multiply, and storage of milk in open containers can enable contamination from the environment.

\section{Effectiveness of Pasteurization}

Comparing pasteurized milk to the goals described above, $96 \%$ of samples had SPC $<20,000$ or $<10,000$ $\mathrm{cfu} / \mathrm{mL}$. Nearly all samples met the target of $<5,000$ $\mathrm{cfu} / \mathrm{mL}$ for $\mathrm{ES}, \mathrm{CNS}$, and $\mathrm{NC}(98,99$, and $100 \%$, respectively); $92 \%$ had $\mathrm{CC}<100 \mathrm{cfu} / \mathrm{mL}$ and $80 \%$ had $<10$ $\mathrm{cfu} / \mathrm{mL}$ of coliforms (Table 2). Overall, pasteurized milk contained acceptable numbers of bacteria in $>90 \%$ of samples. All bacteria counts measured were lower after pasteurization $(P \leq 0.001$; Table 3$)$ than in raw milk. These results indicate that pasteurization can be very effective in lowering bacterial contamination of milk.

Table 4 presents the log reduction in bacteria counts following pasteurization; least squares means were

Table 2. Distribution (\% of total samples) of bacteria counts in milk before and after pasteurization and before being fed to calves (bucket) on 6 Pennsylvania dairy farms ${ }^{1}$

\begin{tabular}{|c|c|c|c|c|c|c|c|}
\hline Item & \multicolumn{7}{|c|}{ Bacteria count $(\mathrm{cfu} / \mathrm{mL})$} \\
\hline \multicolumn{8}{|l|}{ Standard plate count } \\
\hline After pasteurization & 29 & 29 & 53 & 78 & 96 & 98 & 100 \\
\hline Bucket & 6 & 6 & 17 & 31 & 72 & 87 & 100 \\
\hline \multicolumn{8}{|c|}{ Environmental streptococci } \\
\hline Bucket & 31 & 31 & 38 & 66 & 88 & 94 & 100 \\
\hline \multicolumn{8}{|l|}{ CNS } \\
\hline Before pasteurization & 11 & 11 & 25 & 80 & 94 & 98 & 100 \\
\hline After pasteurization & 68 & 68 & 87 & 96 & 99 & 100 & \\
\hline Bucket & 25 & 25 & 45 & 83 & 88 & 98 & 100 \\
\hline \multicolumn{8}{|l|}{ Coliforms } \\
\hline Before pasteurization & 8 & 8 & 39 & 90 & 99 & 100 & \\
\hline Bucket & 71 & 71 & 74 & 83 & 91 & 96 & 100 \\
\hline
\end{tabular}

${ }^{1}$ Before and after pasteurization $\mathrm{n}=147$; bucket $\mathrm{n}=129$. 
Table 3. Least squares means of bacteria counts $(\log \mathrm{cfu} / \mathrm{mL})$ before and after pasteurization and in buckets as fed to calves on 6 Pennsylvania dairy farms

\begin{tabular}{|c|c|c|c|c|c|c|c|}
\hline \multirow[b]{2}{*}{ Item } & \multirow[b]{2}{*}{ Before $^{1}$} & \multirow[b]{2}{*}{ After $^{1}$} & \multirow[b]{2}{*}{ Bucket $^{2}$} & \multirow[b]{2}{*}{ SEM } & \multicolumn{3}{|c|}{ Comparison $^{3}$ ( $P$-value $)$} \\
\hline & & & & & $\begin{array}{c}\text { Before } \\
\text { vs. after }\end{array}$ & $\begin{array}{c}\text { After } \\
\text { vs. bucket }\end{array}$ & $\begin{array}{c}\text { Before } \\
\text { vs. bucket }\end{array}$ \\
\hline Environmental streptococci & 3.34 & 1.04 & 2.54 & 0.44 & $<0.001$ & $<0.001$ & $<0.001$ \\
\hline CNS & 2.46 & 0.76 & 2.35 & 0.37 & $<0.001$ & $<0.001$ & 0.44 \\
\hline Coliforms & 2.14 & 0.45 & 1.57 & 0.19 & $<0.001$ & $<0.001$ & $<0.001$ \\
\hline
\end{tabular}

${ }^{1} \mathrm{n}=147$.

${ }^{2} \mathrm{n}=129$

${ }^{3}$ Comparisons of samples before and after pasteurization, after pasteurization and as fed to calves (bucket), or before pasteurization and as fed to calves (bucket).

$<2.5$ for all counts. Based on FDA standards for juice pasteurization, Ruzante et al. (2008) suggested that achieving a 5-log reduction in SPC was a reasonable method to estimate pasteurization success for milk fed to calves. In the present study, log reduction of SPC ranged from -1.92 to 5.40 with $\log$ reduction $>5$ in only 5 of 147 samples. Considering that 5-log reduction from an initial count of 1,000,000 would leave $10 \mathrm{cfu} /$ $\mathrm{mL}$ and starting with $10,000 \mathrm{cfu} / \mathrm{mL}$ would result in $0.1 \mathrm{cfu} / \mathrm{mL}$ and that both of these final counts are well below acceptable levels, a 5-log reduction may be more stringent than necessary in calf milk. Furthermore, the log reduction method cannot be used to effectively compare samples that vary widely in initial bacteria load. Percentage log reduction may provide a better method for comparison across samples with a range of initial bacteria counts (Schmidt et al., 1984). A 50\% log reduction is equivalent to a $3-\log$ reduction (final count of $1,000 \mathrm{cfu} / \mathrm{mL}$ ) if the initial count is $1,000,000 \mathrm{cfu} /$ $\mathrm{mL}$ and a 2-log reduction (final count of $100 \mathrm{cfu} / \mathrm{mL}$ ) for an initial count of 10,000 cfu/mL. Therefore, $50 \%$ $\log$ reduction of bacteria counts as a result of pasteurization should yield milk with an acceptably low bacterial load for feeding to calves. In this study, $53 \% \log$ reduction was observed for SPC and all other counts had $\log$ reductions $\geq 74 \%$ (Table 4 ).

Results of this study show that on-farm pasteurization of calf milk can reduce bacteria numbers by as much as $99.999 \%$ (5-log reduction). However, variation in pasteurizer performance was observed on all farms. High levels of bacteria in pasteurized milk primarily stem from failure to heat milk to the proper temperature or hold it at that temperature long enough, which could be caused by operator error or system design, or from poor cleaning of the machine. High levels of bacteria in raw milk have also been suggested as a cause of unacceptable bacteria counts in pasteurized milk (Scott, 2006). However, in this study and the results of Jorgensen et al. (2006), SPC of milk before pasteurization was not correlated with SPC after pasteurization $(P>0.05)$.

Type of pasteurizer had no effect on bacteria counts after pasteurization, log reduction, or percentage log reduction $(P>0.05)$ for any of the bacteria studied.

\section{Milk Fed to Calves}

Compared with the goals for bacteria counts described above, $\mathrm{SPC}$ was $<20,000 \mathrm{cfu} / \mathrm{mL}$ in $79 \%$ of the samples

Table 4. Least squares means (LSM) of log reduction and percentage log reduction in bacteria counts following pasteurization of milk fed to calves on 6 Pennsylvania dairy farms $(\mathrm{n}=147)$

\begin{tabular}{lccccc}
\hline & \multicolumn{2}{c}{ Log reduction $^{1}$} & & \multicolumn{2}{c}{ Percentage log reduction $^{2}$} \\
\cline { 2 - 3 } \cline { 5 - 6 } Item & LSM & SEM & & LSM & SEM \\
\hline Standard plate count & 2.21 & 0.75 & & 52.73 & 14.85 \\
Environmental streptococci & 2.39 & 0.44 & & 73.85 & 18.92 \\
CNS & 1.70 & 0.34 & & 74.53 & 13.67 \\
Coliforms & 1.64 & 0.33 & & 77.16 & 17.26 \\
Noncoliforms & 1.37 & 1.26 & & 95.47 & 4.80 \\
\hline
\end{tabular}

${ }^{1} \log$ reduction $=\log _{10}(\mathrm{cfu} / \mathrm{mL}$ before pasteurization $)-\log _{10}(\mathrm{cfu} / \mathrm{mL}$ after pasteurization $)$.

${ }^{2}$ Percentage $\log$ reduction $=100 \times\left[\log _{10}(\mathrm{cfu} / \mathrm{mL}\right.$ before pasteurization $)-\log _{10}(\mathrm{cfu} / \mathrm{mL}$ after pasteurization $\left.)\right]$ $\log _{10}(\mathrm{cfu} / \mathrm{mL}$ before $)$; percentage $\log$ reduction could not be determined for samples with a zero count before pasteurization. 
and $<10,000 \mathrm{cfu} / \mathrm{mL}$ in $72 \%$ of the samples from milk fed to calves (Table 2). Environmental streptococci, CNS, and $\mathrm{NC}$ were $<5,000 \mathrm{cfu} / \mathrm{mL}$ in 88,88 , and $90 \%$ of calf bucket samples, respectively. Coliform count was $<100 \mathrm{cfu} / \mathrm{mL}$ in $56 \%$ of samples and $<10 \mathrm{cfu} / \mathrm{mL}$ in $36 \%$ of samples. All bacteria counts measured increased between pasteurization and feeding $(P<0.001$; Table $3)$. In the case of CNS, bacteria counts in milk fed to calves were similar to those observed in raw milk before pasteurization $(P=0.44$; Table 3$)$.

These results indicate that milk was frequently contaminated between pasteurization and feeding on the farms in this study. When pasteurization is incomplete, bacteria that survive can grow rapidly in warm milk. Other potential causes of high bacteria count in milk fed to calves are poor cleaning of the pasteurizer, prolonged time between pasteurization and feeding that allows bacteria to multiply, lack of refrigerated storage between pasteurization and feeding, uncovered storage of milk between pasteurization and feeding, poor or infrequent cleaning of feeding equipment, and scratched or hard-to-clean feeding equipment. None of these aspects were specifically measured in this study. If bacteria counts are reduced by pasteurization, but increase to prepasteurization levels before feeding, the costs and labor of pasteurization will be more difficult to justify. Although many of the environmental bacteria evaluated in this study are not known calf pathogens, the presence of coliforms in milk suggests fecal contamination, which could allow reintroduction of pathogens including Mycobacterium avium ssp. paratuberculosis to milk between pasteurization and feeding. In addition, milk in this study was relatively low in bacteria before being pasteurized, but conditions that allow growth of the bacteria studied may also encourage growth of more serious calf pathogens. Some of the factors related to increases in bacteria counts observed in this study are unique to pasteurized milk systems. However, many of the factors affecting bacteria counts in milk fed to calves, such as feeding equipment cleanliness, apply equally to other liquid feeding systems. To the authors' knowledge, bacteria count changes between mixing and feeding have not been studied for milk replacer systems, but it is possible that similar patterns could exist. Considering the potential for disease transmission within a vulnerable population, further investigation into bacterial loads of liquid feeds presented to calves is warranted.

\section{ACKNOWLEDGMENTS}

This research was a component of NC-1042: Management Systems to Improve the Economic and Environmental Sustainability of Dairy Enterprises. Sincere appreciation is extended to Beth Houser (Department of Veterinary and Biomedical Sciences at Penn State) for laboratory assistance.

\section{REFERENCES}

Food and Drug Administration. 2003. Grade A Pasteurized Milk Ordinance. http://www.cfsan.fda.gov/ ear/pmo03toc.html Accessed Apr. 2, 2010.

Godden, S., J. Fetrow, J. Feirtag, S. Wells, and L. Green. 2005. A review of issues surrounding the feeding of pasteurized nonsaleable milk and colostrum. http://www.extension.umn.edu/ dairy/05dairydays/pasteurized_milk-dairydays05.pdf Accessed Apr. 2, 2010.

Jayarao, B. M., S. R. Pillai, A. A. Sawant, D. R. Wolfgang, and N. V. Hegde. 2004. Guidelines for monitoring bulk tank milk somatic cell and bacterial counts. J. Dairy Sci. 87:3561-3573.

Jorgensen, M. A., P. C. Hoffman, and A. J. Nytes. 2006. Case study: A field survey of on-farm milk pasteurization efficacy. Prof. Anim. Sci. 22:472-476.

McGuirk, S. M. 2003. Solving calf morbidity and mortality problems. http://www.vetmed.wisc.edu/dms/fapm/fapmtools/8calf/calfmorbid.pdf Accessed Apr. 2, 2010.

Ruzante, J. M., I. A. Gardner, J. S. Cullor, W. L. Smith, J. H. Kirk, and J. M. Adaska. 2008. Isolation of Mycobacterium avium ssp. paratuberculosis from waste milk delivered to California calf ranches. Foodborne Pathog. Dis. 5:681-686.

Sawant, A. A., S. R. Pillai, and B. M. Jayarao. 2002. Evaluation of five selective media for isolation of catalase-negative gram-positive cocci from bulk tank milk. J. Dairy Sci. 85:1127-1132.

Schmidt, A. L., S. P. Oliver, and M. E. Fydenkevez. 1984. Evaluation of experimental teat dip containing sodium chlorite and lactic acid by excised teat assay. J. Dairy Sci. 67:3075-3080.

Scott, M. C. 2006. Viability of waste milk pasteurization systems for calf feeding systems. MS Thesis. Virginia Polytech. Inst. State Univ., Blacksburg.

Stabel, J. R. 2001. On-farm batch pasteurization destroys Mycobacterium paratuberculosis in waste milk. J. Dairy Sci. 84:524-527.

Stabel, J. R., S. Hurd, L. Calvente, and R. F. Rosenbusch. 2004. Destruction of Mycobacterium paratuberculosis, Salmonella spp., and Mycoplasma spp. in raw milk by a commercial on-farm high-temperature, short-time pasteurizer. J. Dairy Sci. 87:2177-2183. 